\title{
VERBÁLIS ÉS VIZUÁLIS AGRESSZIÓ ONLINE: AZ INTERNETES TROLLOK
}

\author{
Veszelszki Ágnes \\ agnes.veszelszki@uni-corvinus.hu,www.veszelszki.hu
}

D O I : 10.20520/ JEL - K E P.2017.2.17

\begin{abstract}
Absztrakt
Troll a sok résztvevős virtuális kommunikációban szándékosan zavart, széthúzást keltő személy, provokatör, aki olyan identitást konstruál, mintha a csoport tagja szeretne lenni, ám valós „célja a diskurzus, valamint a közösség bomlasztása és/vagy egy konfliktus előidézése, illetve elmélyítése a saját szórakoztatására" (Hardaker 2010: 237). Általában gyülölködő megjegyzésekkel, személyeskedéssel vagy a témától eltérő hozzászólásokkal próbál zavart kelteni. A romboló tevékenységet trollkodásnak nevezik. A troll nyelvi viselkedést funkcionális kognitív pragmatikai szempontból elemző Petykó Márton (2013: 281) szerint „az identitáskonstruálás során a nyelvi identitásgyakorlatok dominálnak", mert az interakcióban korlátozott a nem nyelvi eszközök (képek) használata. A tanulmány célja annak bemutatása, hogy az internetes trollkodásnak valóban jellemzője a verbális identitáskonstruálás, ám dominánsan vizuális eszközei is lehetnek.
\end{abstract}

\section{Kulcsszavak}

trollkodás, identitáskonstruálás, verbális agresszió, vizuális agresszió, közösségi média

\section{VERBALANDVISUALAGGRESSION ONLINE: T R O L L I N G}

\section{Ágnes Veszelszki}

\begin{abstract}
In virtual communication involving multiple participants, a troll is a person who intentionally causes disturbance and disagreement, a provocateur, "a CMC user who constructs the identity of sincerely wishing to be part of the group in question [...], but whose real intention(s) is/are to cause disruption and/or to trigger or exacerbate conflict for the purposes of their own amusement" (Hardaker 2010: 237). Trolls usually try to disturb communication with hateful or personal remarks, incomprehensible or irrelevant comments. According to Petykó (2013: 281), who examined the troll linguistic behaviour from a functional cognitive pragmatic aspect, "the process of identity construction is dominated by linguistic identity practices", as the use of non-linguistic tools (images) is restricted for the participants in interaction. The paper argues that although internet trolling is indeed characterised by verbal identity construction, it may also apply primarily visual tools.
\end{abstract}

\section{Keywords}

trolling, identity construction, verbal aggression, visual aggression, social media 


\title{
VERBÁLIS ÉS VIZUÁLIS AGRESSZIÓ ONLINE：AZ INTERNETES TROLLOK
}

\author{
Veszelszki Ágnes
}

\section{Bevezető}

A közösségi média használata olyan erőteljesen és mindent áthatóan jelen van a társadalmunkban, hogy könnyen elfeledkezünk róla, hogy alig két évtizede terjedt el globálisan. A Myspace 2003-ban, a Facebook 2004-ben, a Twitter 2006-ban, az Instagram 2010-ben, a Pinterest és a Snapchat 2011-ben, a Periscope mindössze 2015-ben indult. Vagyis 2016-ban a legrégebbi, széles körben is használt közösségi oldal is kevesebb, mint tizenöt éves, a legfiatalabb pedig alig néhány hónapos (vö. Rampton 2016). A közösségi oldalak e bő másfél évtized alatt azonban tagadhatatlanul nyomot hagytak a társadalmon, a kommunikációs viselkedésen, a gondolkodásmódon. A következőkben egy újfajta internetes (azon belül is elsősorban közösségi médiabeli) szerepről, a troll viselkedésröl lesz szó. A trollok nem csupán a közösségi médiában vannak jelen (az első troll-leírások már az 1980-as évekből utalnak a megjelenésükre: Doyle 1989; Maddox 1989; vö. Hardaker 2013: 58), ám a cikkben bemutatott tevékenységüket leginkább a közösségi oldalakon fejtik ki.

A troll identitást és nyelvi viselkedést funkcionális kognitív pragmatikai szempontból elemző Petykó Márton szerint ,,az identitáskonstruálás során a nyelvi identitásgyakorlatok dominálnak, mivel a résztvevök - különösképpen a hozzászólók - számára korlátozott a nem nyelvi eszközök (pl. képek) használata az interakcióban" (Petykó 2013: 281). E tanulmányban azt kívánom megmutatni, hogy az internetes trollkodásnak valóban fö jellemzője a verbális identitáskonstruálás, ám dominánsan vizuális eszközei is lehetnek.

Ennek elemzéséhez előbb áttekintem az online agresszió verbális és vizuális formáit, bemutatom a trollkodást mint internetes szerepet (a trolltípusokat, trollstratégiákat és a trollok előfordulási területeit), majd a trollkodás verbális és vizuális formáira hozok példákat, végül ismertetek néhány lehetőséget a trollkodás kezelésére. A munka a vizuális kommunikáció és az agresszió egyik formájaként értelmezett trollkodás összekapcsolását, a jelenség első dokumentálását célozza, és az illusztrációkon keresztül bemutatja, hogy lehetséges vizuális tartalmak használatával is trollkodni. A tanulmánynak a szoros tématartás végett nem célja az online énreprezentáció és a troll identitáskonstrukció együttes analizálása. A vizuális trollstratégiák részletes bemutatása és empirikus elemzése egy következő vizsgálat tárgya lehet.

\section{Az online agresszió formái}

A nemzetközi szakirodalom eredményeit figyelembe véve feltételezhető, hogy a digitális/ online kommunikáció a kvázi-anonimitása, a retorzió hiánya vagy gyengesége miatt az offline kommunikációhoz képest durvább, több sértést, személyeskedést tartalmaz (vö. a korai internetpszichológiai munkák közül: Wallace 2006: 143; újabban: Hardaker 2013), amelyek felol- 
dására, kezelésére egyelöre nincsenek kidolgozott nyelvhasználati stratégiák, csupán (főként közösségi marketinges) tanácsadások, útmutatók.

Az agresszió az ember egyik legalapvetőbb viselkedési mintázata. Azt mondják, hogy az első ember, aki elkezdte sértegetni a társát, ahelyett, hogy egy szó nélkül megütötte volna, ezzel a cselekedettel egyúttal lerakta a civilizáció alapjait is (Hughlings Jackson 1879/1958: 179). Természetesen nem azt állítom ezzel, hogy a bántás, a sértegetés, a verbális agresszió pozitív jelenség lenne, ám hozzátartozik az együttéléshez, és meg kell tanulni a kezelését.

A verbális agresszió „olyan verbális viselkedésforma, olyan verbális aktus, melynek során a beszélő szándéka az, hogy direkt vagy indirekt módon (de mindenképpen szándékosan), az elhangzott nyelvi megnyilatkozás tartalma és/vagy minősége [... például emelt hangerö] folytán egy másik személyt bántalmazzon, szidalmazzon, sértegessen” (Kegyesné Szekeres 2008: 61). A verbális agresszió bizonyos formái (mint például a rágalmazás, a becsületsértés, zsarolás) a büntetőjogi szempontból is szankcionált cselekedetek közé tartoznak. Enyhébb, a mindennapokban előforduló, büntetéssel nem vagy csupán szociális/pszichológiai szankcióval járó típusai a káromkodás és a másik megsértése vagy sértegetése. A verbális agresszió ugyanúgy károkat okoz az agresszió elszenvedőjének, mint a fizikai erőszak. „A megnyilvánulási formák sokféleségét vizsgálva azt tapasztalhatjuk, hogy bármilyen nyelvi elem, nyelvhasználati sajátosság, társalgásszervezési mód [...] válhat az agresszió hordozójává. Az agresszió megjelenhet [többek között] a hangerőben, a hanglejtésben, a szóhasználatban, a fogalmazásmódban, az irónia alkalmazásában, a beszédpartner félbeszakításában [...]" (Domonkosi 2008: 54).

Megkülönböztethető egymástól a közvetett és a közvetlen verbális erőszak (vö. Buss 1961; Pulkkinen 1987; Berkowitz 1994; Tóth 2007). Direkt verbális agressziónak szokás tekinteni a csúfolást, a beszólást, az ugratást, a beszédpartner minősítgetését, szidalmazását, illetve az átkot, a káromkodást, a durva szavak használatát. A nyelvi agresszió indirekt formában - hazugságként, rágalmazásként, rosszindulatú pletykaként, intrikaként - is megnyilvánulhat (söt a viccek egyes formái is idesorolhatók).

A vizuális agresszió kérdéséről még viszonylag kevés kutatási eredmény áll a rendelkezésünkre. A témakörrel kapcsolatos lehetséges fö kutatási kérdések: Milyen mértékben lehet a képi (vagy audiovizuális) információ bántó? A verbális vagy a vizuális közeg számíthat sértőbbnek? A digitális kommunikációban a technológia fejlődése révén is folyamatosan erősödik a képi (vizuális) információátadás jelentősége. A verbális nyelv lineárisan dekódolható, konvencionalizált szimbólumaival szemben a vizuális nyelv könnyen és gyorsan befogadható. A képi információ befogadása eltér a verbális információ feldolgozásától, ily módon különösen nagy és a szövegekétől eltérö szerepük lehet a bántó magatartásformák közvetítésében. Az internetpszichológiával foglalkozó Wallace elemez egy e-mailben eszkalálódó konfliktust (az eset ugyan régi, ám jelenleg is megállja a helyét), amelyben vizuális jelek, az emotikonok is szerepet kaptak: amíg a levelezés hangneme semleges volt, a mosolyjelek elvették a mondottak esetleges élét, ,ám a valóban durva üzeneteket csak még gúnyosabbnak" láttatták (Wallace 2006: 155).

A digitális kommunikációbeli sértések kapcsán jellegzetes problémát jelent az ,álcázás": igen gyakran előfordul, különösen internetes kommunikációban, hogy az agresszív viselkedést tanúsító fél nem vallja be, nem teszi explicitté, hogy tudatában van annak, hogy viselkedésével másokat bánt(hat), sért(het), sőt éppen ellenkezőleg, kifejezetten letagadja ezt (viccként, humorként, esetleg iróniaként állítja be a bántó megjegyzéseket). A trollok egy típusa is csak addig tud diskurzusbomlasztó szereplöként részt venni a beszélgetésben, amíg valamely másik résztvevő le nem leplezi ezt a viselkedést. Ugyanígy történhet ez az online zaklatás kapcsán: a cyberbullying elkövetője egészen sokáig leplezheti évődésként, viccelödésként a bántó magatartást (ez is egyfajta manipulatív stratégiaként értelmezhető). Kérdéses, hogy mikor jut el a diskurzus arra a pontra, amikor az évődés már kifejezetten sértésnek, sőt 
zaklatásnak minősül. Természetesen vannak könnyebben azonosítható esetek is, ide tartoznak a direkt sértések, a durva szavak, káromkodások. Ám ezek esetében is felmerülhet a kérdés, egy-egy durva szó tényleg bántó szándékú-e, vagy csupán a csoportnyelvi norma része az adott közösségben (például: németországi török fiatalok in-group verbális inzultusai, Günthner 2008: 64-69).

Bár a korai internetkommunikációs kutatások az agresszió fokozott jelenlétét a fizikai távolsággal és a névtelenséggel magyarázták (például Wallace 2006: 160; Hardaker 2013: 59), a közösségi oldalakra a korábban tipikus anonim (vagy az álnevek által kvázi-anonim) online jelenlét helyett a névvel vállalt digitális identitás megjelenítése jellemző (Veszelszki 2015a). Annak ellenére, hogy például a Facebookon a felhasználók névvel, képpel és (legalább részben) nyilvános profiloldallal azonosíthatók, nem csökkent a kommentekben a verbális agreszszió mértéke (vö. Veszelszki 2017).

\section{A troll mint internetes szerep}

Troll a sok résztvevős virtuális kommunikációban (például internetes fórumon, közösségi oldalon) szándékosan zavart, széthúzást keltő személy, provokatőr (Veszelszki szerk. 2012), a számítógép közvetítette diskurzusok résztvevője, aki olyan identitást konstruál, mintha az adott csoport tagja szeretne lenni, ám valós „,célja a diskurzus, valamint a közösség bomlasztása és/vagy egy konfliktus elöidézése, illetve elmélyítése a saját szórakoztatására" (Hardaker 2010: 237). Általában gyülölködő megjegyzésekkel, személyeskedéssel vagy követhetetlen, a témától eltérő kommentárokkal próbál zavart kelteni (Shin 2008). A romboló tevékenységet trollkodásnak nevezik. „Az online trollkodás megtévesztő, destruktív vagy zavaró viselkedési forma, amely az internet társas közegében jelenik meg, és nincs egyértelmüen körülhatárolható célja" ${ }^{2}$ - állítja Buckels-Trapnell-Paulhus (2014: 97).

A troll a nevét - az egyik etimológia szerint - a skandináv mondavilágból ismert, a fantasy irodalomban, illetve a szerepjátékokban kötekedő, agresszív lényként felbukkanó figuráról kapta (W1). A másik elmélet szerint az elnevezés a trolling tengeri horgászati technikából ered, amely során a horgász a mozgó csónakból vagy hajóból kivetett csalit elhúzza a halak előtt (W2; Petykó 2013: 274).

Claire Hardaker (2010) a troll viselkedés nyelvi udvariassággal összekötött leírásához a megtévesztés/csalás, az agresszió, a bomlasztás és a siker fogalmait használja. A trollkodás ezek mellett más társas jelenségekkel is kapcsolatban áll(hat), többek között a manipulációval, a sértéssel és a beszólással. A manipuláció a befolyásolás egyik típusa, és azt a célt szolgálja, hogy a befolyásoló hatással legyen a másik gondolataira, véleményére, érzelmeire, viselkedésére (általában olyan módon, hogy erről a manipulált ne szerezzen tudomást; vö. Van Dijk 2006). A sértés domináns helyzetet kölcsönözhet a sértőnek, és/vagy megjelenítheti a már meglévő vagy feltételezett domináns hatalmi helyzetét (Veszelszki-Falyuna-Fodorné TóthTóth m. a.). A sértés egyik indítóoka ugyanis ,többnyire a hatalomért, dominanciáért folytatott küzdelem, a címzett felidegesítése, provokálása, de lehet egyszerüen negatív érzelmek, frusztráció levezetése is" (Heltai 2016: 2). A megnyilatkozó a beszólással is a másik fölé helyezi magát, negatívan értékeli, lejáratja a másikat, és emellett a saját pozitív énképét is

${ }^{1}$ Eredetiben: „A troller is a CMC user who constructs the identity of sincerely wishing to be part of the group in question, including professing, or conveying pseudo-sincere intentions, but whose real intention(s) is/are to cause disruption and/or to trigger or exacerbate conflict for the purposes of their own amusement."

2 Eredetiben: "Online trolling is the practice of behaving in a deceptive, destructive, or disruptive manner in a social setting on the Internet with no apparent instrumental purpose." 
erősítheti. Mivel ha valakit negatívan értékelünk, azt is kifejezhetjük ezzel, hogy a kimondott szavaink ránk nem érvényesek (Batár 2007; Veszelszki-Falyuna-Fodorné Tóth-Tóth m. a.).

A trollkodásban a humor és az agresszió is összekapcsolódik. A humor elnevezés azokat a nem-komoly, játékos, nem fenyegető kommunikatív tevékenységeket foglalja össze, amelyek kognitív inkongruenciát, valamennyi agressziót, pszichológiai megkönnyebbülést és a freudi elnevezéssel élve „Witzarbeit”-ot, azaz viccmunkát foglalnak magukban (Brock 2008: 555; Freud 1905/1985). Több szerzö fontosnak tartja kiemelni a meglepetés erejét is. A humor, multifunkcionalitása miatt, kifejezetten hatékony kommunikációs eszköz (Brock 2008: 555). Noha különféle humorformák vannak, az agresszióelméletek szerint, a humornak van (legalább enyhén) agresszív komponense is (Norrick 2001: 1438). Az agresszív humor szándékosan és rendszerint rosszindulattal egy áldozatra irányul: vagy egy közvetlen címzettre, vagy egy jelen vagy távol lévő harmadik személyre (Brock 2008: 551). Az agresszív típusú humor különösképpen hatékony a csoportalakításban (és ezzel együtt a csoporton kívüliek kirekesztésében), illetve a hatalom és dominancia kifejezésében.

\section{Trolltípusok}

Rudas Judit (2016) vizsgálatában a kommunikációs partner(ek)hez füződő viszony alapján két fő trolltípust különít el egymástól. Meglátása szerint a provokatív troll egy, az érzelmek felkorbácsolására alkalmas hozzászólással (amelyet azonban sokszor komoly állításnak vagy kérdésnek álcáz) próbálja felhívni magára a figyelmet, illetve szétrombolni a beszélgetést. A reaktív troll ezzel szemben egy célpontot keres, és öt inzultálja az áldozat szavainak, érveinek a kiforgatásával vagy még gyakrabban személyeskedéssel.

Rudas (2016) kategorizációjának felhasználásával és kiegészítésével a leggyakoribb trollviselkedések a következők: 1 . Az „elsőző” trollok főként YouTube-videók alatt jelennek meg, és a kommentjük mindössze az „első” szó beírásából áll. 2. Az agresszív, személyeskedő trollok hozzászólásai durvák, erőszakosak, nemegyszer obszcének. A tartalomtól függetlenül minden esetben negatív véleményüket hangsúlyozzák, az ellenérveket nem fontolják meg, csupán személyeskedő megjegyzéseket tesznek. Formai szempontból jellemző rájuk a csupa nagybetü (caps lock) használata, a kiabálás szimbolizálására. 3. A politikai nézetet vagy vallási hovatartozást hangoztató troll bármely téma kapcsán (ugyanazt) a számára érzékeny vagy fontos politikai/vallási kérdést hozza elö, és ellenvéleményt nem tolerál. 4. A „mindentudó” valamilyen információs bizonytalanság esetén azonnal jelzi, hogy ő ki tudja egészíteni vagy javítani az elhangzottakat. Jellemző rá az irónia vagy a nyílt gúny használata (például: Szerinted én nem értek hozzá jobban orvosként?). 5. A „mindentudó” egyik válfaja a nyelvtannáci vagy grammar nazi, aki a kommunikációs partnereinek vélt vagy valós helyesírási vagy grammatikai hibáiba köt bele, kioktató, gúnyos stílusban, ritkábban segítő szándékkal. 6. Éppen a grammar nazikat akarják bosszantani a nyelvtantrollok, akiknek a stratégiája az, hogy szándékosan butának, tudatlannak mutatják magukat, amibe beletartozik a szándékosan hibás írás is. Céljuk, hogy a nyelvtannácikat provokálják, és ideges kommenteket, illetve javításokat kapjanak tőlük (W3). 7. A mémosztó ismeri a legfrissebb népszerü internetes tartalmakat, és akár oda nem illő téma kapcsán is az éppen aktuális mémet (szöveget, képet vagy videót) használja hozzászólásként. 8. Az emotikonokkal operáló troll hozzászólása általában nehezen értelmezhető, tartalmilag nem füz hozzá semmit a beszélgetéshez, csak egy jelet küld a beszélgetéshez, és gyakran kineveti az előző hozzászólót vagy megosztót (például: $L O L X D$, :DDDDDDDDDDDD). 9. A copypasta troll saját élettörténetként, hitelesnek tűnő módon, vallomásszerüen mesél egy eseménysort, amelyről a narratíva előrehaladásával kiderül, hogy egy film vagy egy zeneszöveg szüzséje. 10. A sokkoló pedig pornográf vagy horrorisztikus képi tartalommal provokálja áldozatát. A lista természetesen nem teljes, számos további trollformával kiegészíthető. 


\section{A trollok elöfordulási területei}

A trollok a több résztvevős online kommunikációs helyzetekben jelennek meg. Az internetezés korábbi időszakában a fórumok, manapság inkább a közösségi hálózatok üzenőfalai vagy csoportjai jelentik számukra a terepet.

Arra, hogy a trollok meglepő helyzetekben is előfordulhatnak, és számukra semmi sem „szent”, egy korábbi, a gyászmunkával foglalkozó vizsgálatunkat hozom példaként (VeszelszkiParapatics 2014, 2016). Ebben a munkában azt elemeztük, hogy milyen formában jelenik a halálról való híradás és a gyászolás folyamata a közösségi oldalakon.

Ritkán ugyan, de negatív hozzászólások is megjelenhetnek az elhunytak emlékoldalán, online esetben akár valós, akár nem valódi ismerősöktől (RIP trolloktól, vö. Camber-Neville 2011), akik a helyzethez nem illő megjegyzéseket írnak a gyászhírhez és részleteihez A moderálás, azaz az ilyen hozzászólások törlésének vagy töröltetésének lehetősége miatt a vizsgált magyar mintában erre nem találtunk példát - utalásokat ezek (egykori) jelenlétére és törlésére viszont igen (például: nem ertem, hogy ti hogy tudjatok elpoenkodni ezt az egeszet!! a hulye kommentekrol meg nem is beszelve, AZERT EGY KIS TISZTELETET MEGERDEMELNE!! gondolkozzatok, mielott barmit is kiirtok!!!; Nem tudom ki és mivel poénkodik, de nem is érdekel. Nem kívánom, hogy élje át ö is amit most a családja érez, de kíváncsi lennék, hogy akkor is poénkodna-e? Ha már a tiszteletet nem tudja megadni akkor legalább hallgasson.). A rosszindulatú trollok illetlen kommentjei konfliktusok forrásai lehetnek a gyászoló családtagok, a velük valóban együttérző hozzászólók, illetve az illetéktelenek között. A gyászolók ilyenkor rendszerint a törlés, a moderálás már említett lehetőségével élhetnek, vagy továbbra is hangot (posztot) adnak traumafeldolgozási nehézségeiknek.

\section{Trollstratégiák}

A trollok felismerése, azaz a trollkodás trollkodásként való azonosítása rendszerint nehézségekbe ütközik. ${ }^{3}$ Hardaker (2013: 62-64) a beszélői intenciók rekonstruálása és a hallgatói feltételezések közötti szürke zónáról beszél. ${ }^{4}$ Hiszen nem tudható, hogy 1 . valóban szándékose a támadó jellegünek érzett megszólalás, vagy csupán a kontextus, a befogadói értelmezés teszi-e azzá, vagy 2. valódi tudatlanságról van-e szó egy megnyilvánulás esetében, vagy pedig szándékosan megtévesztő a naivitás (és a hibás írásmód). Ez utóbbi dilemma merülhet fel a következő kérdés esetében, amelyet egy Facebook-használó posztolt egy, a magyarországi közéletben aktív szerepet vállaló, ismert nemzetközi jogász egyik (egyébként teljesen más témájú) posztja alá: „, X úr ,mint nemzetközi jogász ,nem tudna segiteni a deviza hiteleseken ?” (eredeti írásmóddal). A kérdésre nem érkezett válasz, tehát nem derült ki a trollkodás ténye, csak a gyanú állhat fenn.

Egy leleplezett trollkodás hívja fel a figyelmet az önmagát butának tettető trollfajtára. A trollok sajátos változatát jelenti az a típus, amely azzal téveszti meg a befogadókat, hogy szándékosan tudatlannak mutatja magát, ezzel gúnyolva ki a tudatlanságot, a müveletlenséget, az interneten virulensen terjedő téves, áltudományos eszméket, mozgalmakat. Ennek példája

3 Több mint ötszáz kitöltő válaszolt Rudas Judit (2016) képekkel alátámasztott kérdőívére, amelyben azt kérte a válaszadóktól, hogy állapítsák meg, hogy a megadott szituációban trollkodásról van-e szó. A módszer azt a kérdést is fölveti, hogy a laikus nyelvhasználó vagy pedig a metanyelvi tudással is rendelkező kutató tudja-e hatékonyabban, a szubjektív tényezőket kiküszöbölve (?) azonosítani a trollokat.

${ }^{4}$ Vö. ezzel kapcsolatban az udvariassági elméletekben az on-record és off-record udvariatlansági stratégiákat (Brown-Levinson 1978; Szili 2007: 10). 
lehet a 1. és 2. ábrán látható facebookos poszt és kommentsorozata, amelyben a kommentelö azt állítja, hogy a 11 éveseknek nincsen veséjük, az csak a pubertáskorban fejlödik ki. Az eset komoly indulatokat gerjesztett, a kommentet képként többen is megosztották, és a képposzt alatt találgatták, vajon komolyan gondolta-e a posztoló azt, amit írt. A rejtélyt az egyik hozzászóló oldotta meg azzal, hogy személyesen ismeri a posztolót, aki gyakorta oszt meg hasonló tartalmú (tárgyi tévedéseket tartalmazó) és formájú (helyesírási hibás) üzeneteket.

1. ábra

Trollkodás (Facebook, 2016. július)

Dániel ite
22 mins - Budapest - a
Kedves Ismerôseim! A vese egy gyülöletkeltõ átverés! Vigyázzatok! (én
szóltam)

2. ábra

Trollkodás (Facebook, 2016. július)

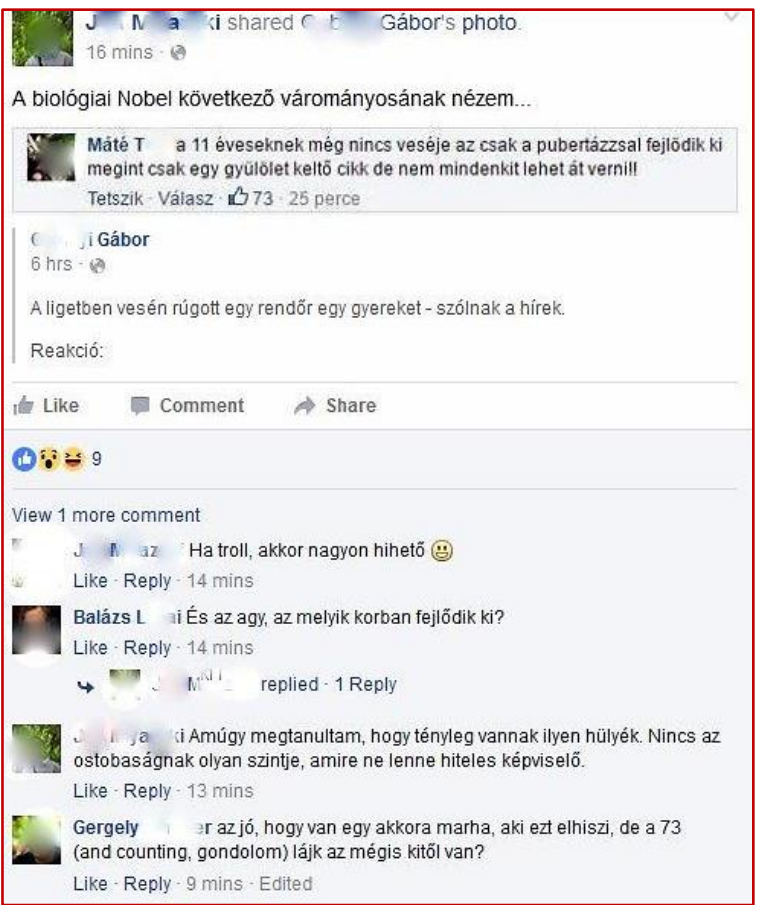


Hardaker (2013) közel 3800 (86 milliónál is több szóból álló) Usenet-felhasználói diskurzust elemzett, és a trollok azonosításához a trollok más felhasználók által történő felismerését vette figyelembe, és nem foglalkozott a beszélői intenciók feltárásával. A nagyméretü korpusz alapján Hardaker a következő hat trollstratégiát különítette el: téma elterelése, kritika és álszentség, ellenkezés-ellentmondás, veszélyeztetés, sokkolás, agresszió (nyílt támadás). ${ }^{5}$ A hat stratégiát a szerző a nyílt, nyilvánvaló és a rejtett kategóriák közötti skálán helyezte el (3. ábra).

3. ábra

Trollstratégiák egy skálán elhelyezve (a szerzö rajza, forrás: Hardaker 2013: 80)

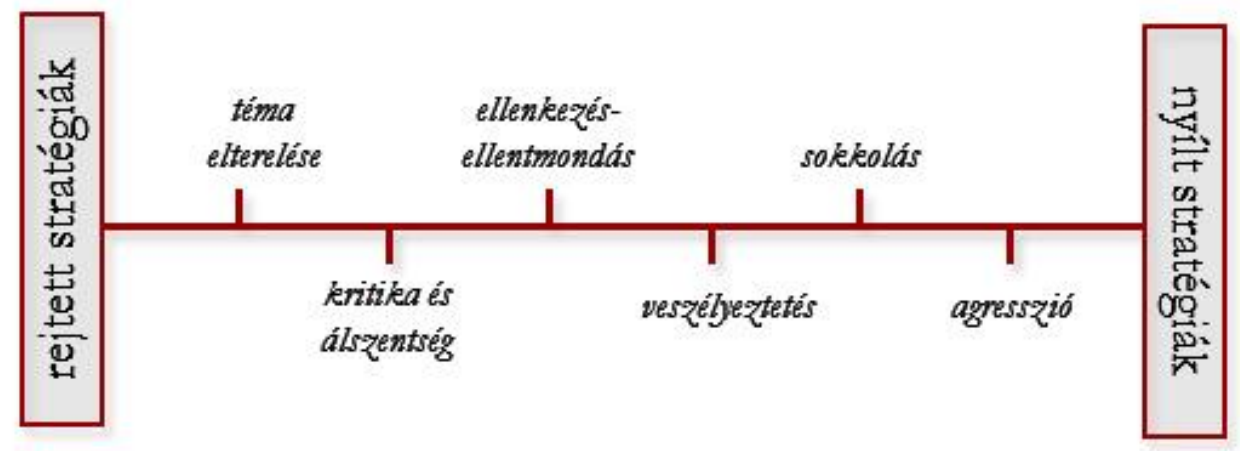

A Hardaker-féle korpusz (adatgyüjtési módszeréből adódóan) csupán verbális elemeket tartalmazott, és a vizuális trollstratégiákat (és a trollkodásra adott képes reakciókat) módszerénél fogva nem vehette figyelembe. Véleményem szerint a vizualitás aspektusát is érdemes a trollokról való diskurzusba bekapcsolni.

\section{A trollok verbális és vizuális eszköztára}

A troll identitás és nyelvi viselkedés magyar nyelvü elemzésével egyelőre csak Petykó Márton foglalkozott, funkcionális kognitív pragmatikai szempontból (2013). Petykó három pontban összegzi a (politikai) diskurzusok trolljainak jellemzőit, amelyek a relatív anonimitás, a gyakorlatközösség alkalmisága és a közös tevékenység nyelvi jellegének következményeként jönnek létre: „1. az identitáskonstruálás során a nyelvi identitásgyakorlatok dominálnak, mivel a résztvevők - különösképpen a hozzászólók - számára korlátozott a nem nyelvi eszközök (pl. képek) használata az interakcióban [...]; 2. viszonylag könnyen kivitelezhetővé válik a megtévesztésen alapuló identitásmanipuláció [...]; 3. a troll mint identitás jellemzően alkalmi, ugyanis annak, ha egy résztvevőt mások az aktuális diskurzusban trollként azonosítanak, csak az aktuális diskurzusban [...] vannak további diszkurzív következményei” (Petykó 2013: 281).

A Petykó által leírt troll-jellegzetességeket a Facebook közösségi oldalon (egy, a Trollfoci oldalán végzett empirikus kutatás alapján; vö. Veszelszki 2015b, 2015c) megvizsgálva a következőket állapíthatjuk meg. A facebookos közösségben - az oldal szabályzata és az általános magyarországi gyakorlat alapján - valódi névvel szokás regisztrálni (ami természetesen nem jelenti azt, hogy ne lennének álnéven létrehozott profilok), tehát a relatív anoni-

5 A visszakövethetőség kedvéért az eredeti fogalmak zárójelben szerepelnek: téma elterelése (digression), kritika és álszentség ([hypo]criticism), ellenkezés-ellentmondás (antipathising), veszélyeztetés (endangering), sokkolás (shocking), agresszió (aggressing); overt vs. covert stratégiák (Hardaker 2013). 
mitás a vizsgált közegre, a Facebook diskurzusára nem jellemzö. A gyakorlatközösség összetétele általában valóban esetleges, ám egy Facebook-oldalon (mint a vizsgált Trollfoci) csak részben alkalmi, hiszen többször ismétlődő, bár változó összetételü és nagyon sok számú szereplővel jön létre a trollhadjárat. Továbbá a Facebook (is) lehetőséget biztosít képes (és részint videó)információk megosztására önálló posztban, illetve kommentben egyaránt. Ezzel a felhasználók élnek is, elsődlegesen mémek formájában, tehát a fenti értelmezés szerint a vizuális információkat kizáró nyelvi tevékenység kitüntetett szerepe erre a diskurzusra nem jellemző. ${ }^{6}$

A következőkben három példát hozok a vizuális trollkodás lehetséges eseteire.

Ha a diskurzust nem egy többszereplős beszélgetésre korlátozzuk, hanem sokkal tágabban értelmezzük, akkor a 4. ábrán szereplő példa vizuális trollkodásnak minősülhet. Egyetlen negatív üzenetet hordozó, virálissá váló fénykép is képes kommunikációs krízist kiváltani. A KFC gyorsétteremlánc egyik vendége 2015 nyarán közzétett egy fotót, amelyen egy patkány alakú húsdarab volt látható, azzal a szöveggel, hogy csirke helyett panírozott patkányt kapott az étteremben (4. ábra). A KFC gyorsan reagált, bevizsgáltatták a húst (amelyet az ügyfél egyébként eltett bizonyítékul), és kiderült, hogy - ugyan furcsa formájú, de - csirkehúst szolgáltak fel. Rosszhírkeltésért bocsánatkérést vártak az ügyféltől, ami azonban azóta sem történt meg (W4). Nem volt ugyan igaz a hír, de groteszk jellege miatt a poszt huszonkétezernél is több megosztást kapott, a téma bekerült a hírmüsorokba, és egyértelmüen negatív hatással volt (és talán van is) az étteremlánc egyik legértékesebb immateriális vagyontárgyára, a hírnevére.

\section{4. ábra}

Vizuális trollkodás a közösségi médiában: egy KFC-vásárló azt állitotta, hogy sült csirke helyett patkányt kapott az étteremben

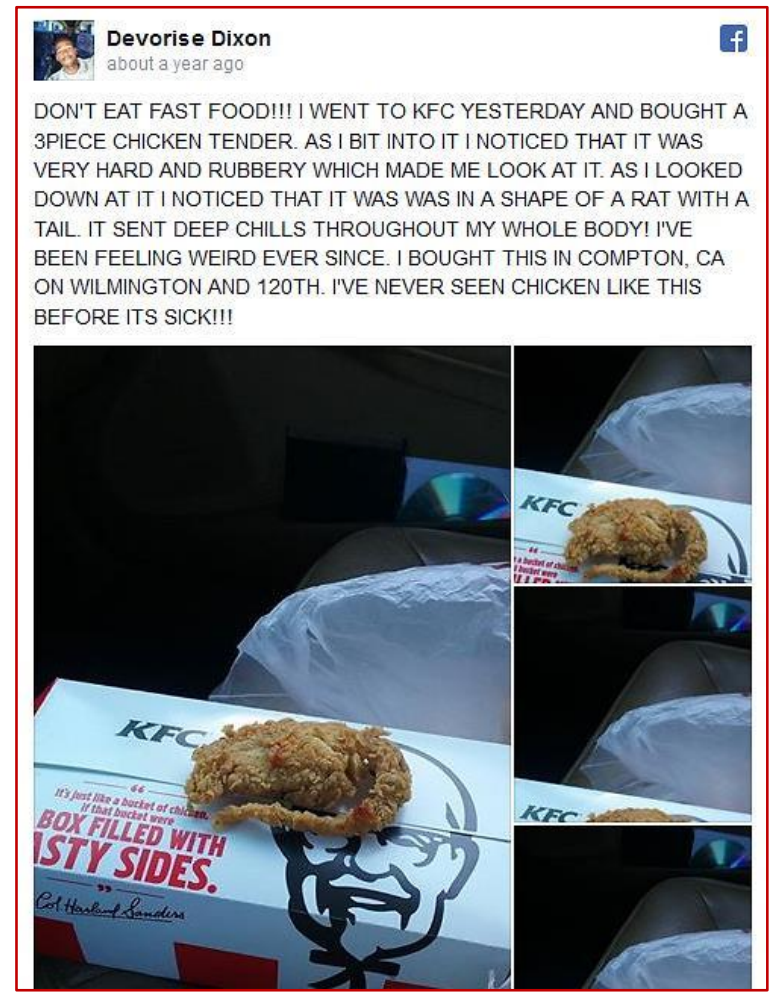

${ }^{6}$ Ennek a lehetőségére utal Petykó is (2013: 281, 6. lábjegyzet). 
A diskurzus fogalom szűkebb értelmezéséhez (vö. Tracy-Mirivel 2009) a következő példa illeszkedhet: diskurzusbomlasztó cselekvésnek számít egy közösségi oldal adminisztrátorai és a lájkolói közötti kommunikáció megakadályozása túlterheléssel, trollhadjárattal. A kimondott módon trollkodó Trollfoci oldal felhasználói képeket is használtak, amikor egy magyar focista, Bajner Bálint átigazolása kapcsán egy angliai futballcsapat Facebook-oldalát elárasztották mémekkel, többek között az ismert Keep calm and carry on feliratú poszter ${ }^{7}$ módosított változataival (5. ábra). A képek (és az átigazoláshoz, illetve a focista nevéhez kapcsolódó hashtagek) folyamatos posztolásával szinte lehetetlenné tették a futballoldal szokványos müködését (az eset elemzése részletesen: Veszelszki 2015b, 2015c). Ebben az esetben az, hogy explicitté tették a trollkodás tényét, nem akadályozta meg a hatást - a támadás tömegessége miatt.

\section{5. ábra}

A Keep calm-sorozat három eleme vizuális trollkodás részeként (forrás: Trollfoci, W5)

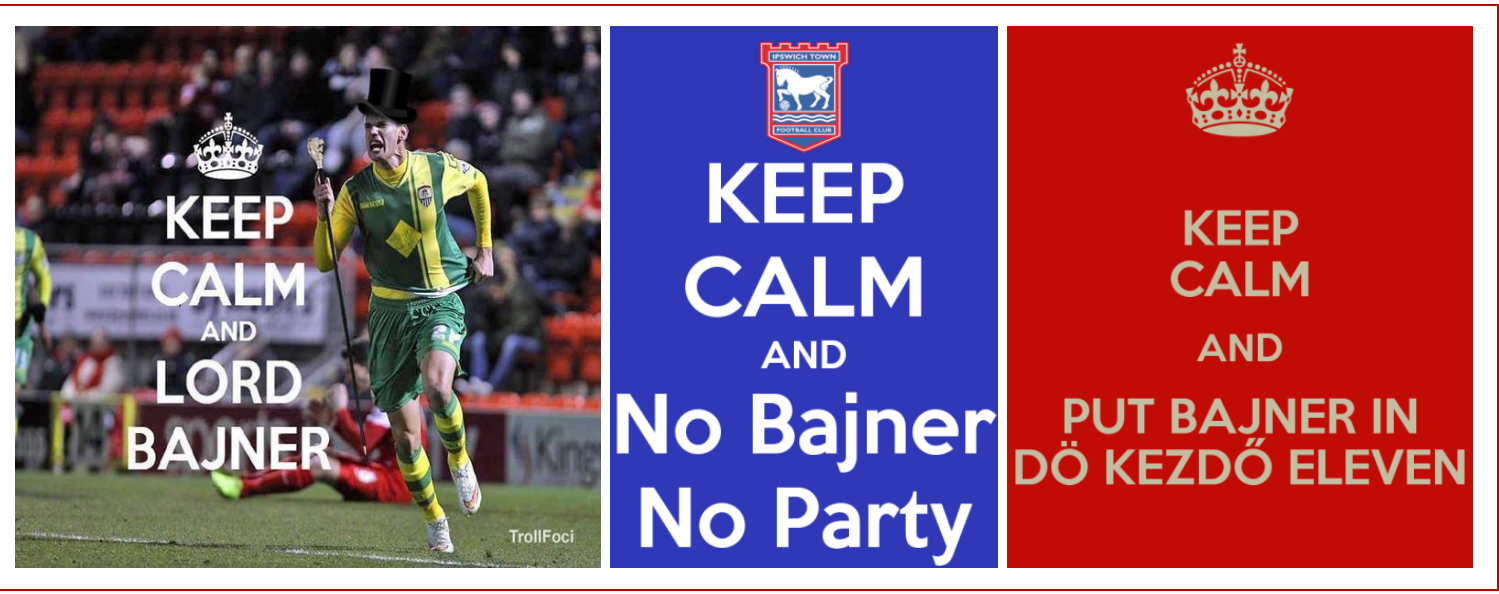

A trollkodás és a vizualitás kapcsolatára harmadik példaként szolgál az ún. trollface figura (vö. Veszelszki 2013; 6. ábra). A mémeket azonosító, csoportosító oldal szerint a trollface „csibészes mosolyú képregényfigura, amely egy internetes troll arckifejezését jeleníti meg. A képet általában arra használják, hogy az ún. rage comics műfajban egy trollt ábrázoljon, vagy pedig a posztolót önmagát vagy egy másik részvevőt trollként azonosítsanak vele"8 (W6). „Ha a trollface-t egy fórumszálba posztolják, az általában arra utal, hogy valakit becsaptak vagy szándékosan felidegesítettek" (W3). Amint a leírásból is látható, a kép mind a troll önazonosítására, mind pedig egy másik résztvevő trollkodásának leleplezésére szolgálhat.

${ }^{7}$ Az eredeti poszter 1939-ben készült Nagy-Britanniában, a második világháborúbeli helytállásra buzdításképpen. A plakát ismertségét a 2000-es újrafelfedezése hozta el (Lewis 2012). Azóta az interneten változatlan vagy módosított formában, képpel vagy kép nélkül jelentős mémmé vált.

${ }^{8}$ Eredetiben: „,comic character wearing a mischievous smile that is meant to represent the facial expression of an internet troll. The image is most commonly used to portray a character as a troll in rage comics, or alternatively, to identify oneself or another participant as such in online discussions".

9 Eredetiben: „Posting a Trollface image into a forum thread is often used to claim that someone was being fooled or intentionally angered". 


\section{6. ábra}

Trollface mint a trollkodás vizuális azonositása

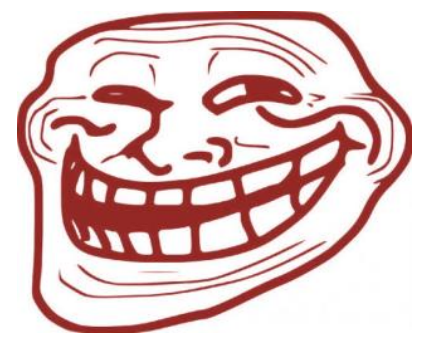

\section{Összegzés. A trollok kezelési módjai}

Az előzőekben a troll viselkedés jellegzetességeit gyüjtöttem össze, és amellett érveltem példáimmal, hogy a vizualitás aspektusa nem zárható ki a trollkodásból, és a troll mint internetes szerep vizsgálatakor a trollkodás vizuális formáit is figyelembe kell venni.

Zárásképpen röviden bemutatom, hogy miképpen kezelhetők a provokáló trollok. A troll viselkedéssel szembeni védekezésről tanácsadó cikkek sokasága jelent meg (vö. a tudományos diskurzusban megjelenő Twitter-trollokkal szembeni védekezésről: Dance 2017). Amit e tanácsok közül különösen érdemes megfontolni, az a folyamatos éberség, az internetes információkkal szembeni kritikus hozzáállás (még tágabban a médiatudatosság). A trollokkal kapcsolatban a legtöbb esetben azt javasolják, hogy: „Ne reagáljunk a szándékosan provokatív megnyilatkozásokra. A trollok mindig is trollkodni fognak. Ne idegesítsük fel magunkat a nyilvánvalóan dühítő kommenteken, amelyek célja a provokáció. Ha mégis dühösen reagálunk, a trollok elérik céljukat. Válasszuk meg jól, mikor érdemes csatázni: ha azt gyanítjuk, hogy valaki csak fel akar dühíteni, ne adjuk meg neki ezt az elégtételt"10 (Elliott 2015). Röviden: „don't feed the troll”, vagyis ne etessük a trollt.

\section{Irodalom}

Batár Levente (2007) A beszólás mint beszédaktus. Magyar Nyelvőr, 131/4. 451-464.

Berkowitz, Leonard (1994) Is Something Missing? Some Observations Prompted by the Cognitive-Associationist View of Anger and Emotional Aggression. In: Huesmann, L. R. (szerk.) Aggressive Behavior: Current Perspectives. New York, Plenum Press. 3557. https://doi.org/10.1007/978-1-4757-9116-7_3

Brock, Alexander (2008) Humor, jokes, and irony versus mocking, gossip and black humor. In: Antos, Gerd - Ventola, Eija (szerk.) Handbook of Interpersonal Communication. Handbooks of Applied Linguistics, Vol. 2. Berlin - New York, Mouton de Gruyter. 541-565. https://doi.org/10.1515/9783110211399.4.541

Brown, Penelope - Levinson, Stephen C. (1978) Universals in language usage. Politeness phenomena. In Goody, Esther N. (szerk.) Questions and Politeness. Strategies in Social

${ }^{10}$ Eredetiben: „Don’t react to deliberately provocative statements. Trolls gonna troll. Don't let yourself rise to obviously inflammatory comments that are only designed to provoke others. If you do, you're giving the trolls what they wanted. Pick your battles - if you suspect someone is just trying to get a rise out of you, don't give him or her the satisfaction." 
Interaction. Cambridge Papers in Social Anthropology 8. Cambridge, Cambridge University Press. 56-232.

Buckels, Erin E. - Trapnell, Paul D. - Paulhus, Delroy L. (2014) Trolls just want to have fun. The Dark Triad of Personality. Personality and Individual Differences, 67. 97-102. https://doi.org/10.1016/j.paid.2014.01.016, https://doi.org/10.4018/ijep.2014100102

Buss, Arnold H. (1961) The psychology of aggression. New York, Wiley. https://doi.org/10.1037/11160-000

Dance, Amber (2017) Communication: Antisocial media. Nature, 543. 275-277. https://doi.org/10.1038/nj7644-275a

Domonkosi Ágnes (2008) A nyelvi agresszió szerepe a személyközi viszonylatokban. In: Zimányi Árpád (szerk.) Az agressziókutatásról interdiszciplináris keretben. Eger, EKF Líceum Kiadó. 53-59.

Donath, Judith (1999) Identity and Deception in the Virtual Community. In: Kollock, Peter Smith, Marc A. (szerk.) Communities in Cyberspace. London, Routledge. 29-59. https://doi.org/10.2307/2655574

Freud, Sigmund (1905/1985) Der Witz und seine Beziehung zum Unbewussten. Leipzig, Gustav Kiepenheuer.

Günthner, Susanne (2008) Interactional Sociolinguistics. In: Antos, Gerd - Ventola, Eija Weber, Tilo (szerk.) Handbook of Interpersonal Communication. Berlin - New York, Mouton de Gruyter. 53-76. https://doi.org/10.1515/9783110211399.1.53

Hardaker, Claire (2010) Trolling in asynchronous computer-mediated communication: From user discussions to academic definitions. Journal of Politeness Research, 6. 215-242. https://doi.org/10.1515/jplr.2010.011

Hardaker, Claire (2013) Uh....not_to_be_nitpicky_but...the_past. Journal of Language Aggression and Conflict, 1/1. 58-86. https://doi.org/10.1075/jlac.1.1.04har

Heltai Pál (2016) A sértés beszédaktusának sajátságosságai. In: Nyelv - nyelvtechnológia nyelvpedagógia: 21. századi távlatok. XXV. Magyar Alkalmazott Nyelvészeti Kongresszus elöadásai. Budapest, PPKE.

Hughlings Jackson, John (1879/1958) On affections of speech from disease of the brain. In: Taylor, J. (szerk.) Selected Writings of John Hughlings Jackson. Volume 2. New York, Basic Books. 184-204. https://doi.org/10.1093/acprof:oso/9780195177640.003.0019

Kegyesné Szekeres Erika (2008) Verbális agresszió és nemi sztereotípiák. In: Zimányi Árpád (szerk.) Az agressziókutatásról interdiszciplináris keretben. Eger, EKF Líceum Kiadó. 61-90.

Lewis, Bex (2012) The Renaissance of 'Keep Calm and Carry On'. The Poster, 2. 7-23. https://doi.org/10.1386/post.2.1.7_1

Norrick, Neal R. (2001) Jokes and joking in conversation. In: Brinker, Klaus - Antos, Gerd Heinemann, Wolfgang - Svager, Sven F. (szerk.) Text- und Gesprächslinguistik. Linguistics of Text and Conversation. Ein internationales Handbuch zeitgenössischer Forschung. An International Handbook of Contemporary Research 2. Berlin - New York, Walter de Gruyter. 1438-1449. https://doi.org/10.1515/9783110194227

Petykó Márton (2013) Az internetes troll mint identitás kialakítása politikai blogok diskurzusaiban. Magyar Nyelvör, 137/3. 274-313. 
Pulkkinen, Lea (1987) Offensive and Defensive Aggression in Humans: A Longitudinal Perspective. Aggressive Behavior, 13. 197-212.

https://doi.org/10.1002/1098-2337(1987)13:4<197::AID-AB2480130404>3.0.CO;2-E

Rudas, Judit (2016) A trollok nyelvi viselkedésének pragmatikai elemzése. BA szakdolgozat, kézirat. Témavezető: Veszelszki Ágnes. Budapest, ELTE BTK.

Shin, Jiwon (2008) Morality and Internet Behavior: A Study of the Internet Troll and its Relation with Morality on the Internet. Technology and Teacher Education Annual Review, 5. 28-34.

Szili Katalin (2007) Az udvariasság pragmatikája. Magyar Nyelvőr, 131/1. 1-17.

Tóth Péter (2007) A médiahatás-kutatás problémái: az agresszió és az erőszak rekonceptualizálása. Médiakutató, 2007. tél.

Online: http://www.mediakutato.hu/cikk/2007_04_tel/05_mediahatas_eroszak

Tracy, Karen - Mirivel, Julien C. (2009) Discourse Analysis: The Practice and Practical Value of Taping, Transcribing, and Analyzing Talk. In Frey, Lawrence R. - Cissna, Kenneth N. (szerk.) Routledge Handbook of Applied Communication Research. New York, Routledge. 153-178. https://doi.org/10.4324/9780203871645

Van Dijk, Teun A. (2006) Discourse and manipulation. Discourse and Society, 17/2. 359-386. https://doi.org/10.1177/0957926506060250

Veszelszki Ágnes - Parapatics Andrea (2014) A részvételtől a részvétig. A halál megjelenése és gyászmunka a közösségi oldalakon. Magyar Nyelvőr, 2014/2. 179-198.

Veszelszki, Ágnes - Falyuna, Nóra - Fodorné Tóth, Krisztina - Tóth, Aliz (m. a.) Az internetbiztonság kommunikáció- és nyelvtudományi aspektusból. In: Fülöp, Hajnalka Kollár, Csaba (szerk.) Internetbiztonság. (megjelenés alatt)

Veszelszki, Ágnes - Parapatics, Andrea (2016) From Cooperation to Compassion: Death and Bereavement on Social Networking Websites. In: Knautz, Kathrin - Baran, Katsiaryna S. (szerk.) Facets of Facebook: Use and Users. Series Knowledge \& Information. BerlinBoston, De Gruyter Mouton. 172-209. https://doi.org/10.1515/9783110418163-008

Veszelszki, Ágnes (2013) Promiscuity of Images. Memes from an English-Hungarian contrastive perspective. In: Benedek, András - Nyíri, Kristóf (szerk.) How To Do Things With Pictures: Skill, Practice, Performance. Frankfurt, Peter Lang. https://doi.org/10.3726/978-3-653-03620-6/12

Veszelszki, Ágnes (2015a) Megfontolások a digitális kommunikáció pragmatikai leírásához. In: Bárdosi, Vilmos (szerk.) A nyelvi pragmatika kérdései szinkrón és diakrón megközelitésben. Budapest, Tinta Könyvkiadó. 239-250.

Veszelszki, Ágnes (2015b) Konfliktuskezelés a közösségi médiában. Esettanulmány a Trollfoci vs. Notts County példáján. Médiakutató, 2015/2. 39-51.

Veszelszki, Ágnes (2015c) Hogyan kezelhetők a trollok a PR eszközeivel? Online konfliktuskezelés egy futballklub Facebook-oldalán. In: Sós Péter János - Szécsi Gábor (szerk.) Jövőkép és konfliktusok: A Public Relations elmélete és gyakorlata. Budapest, Alapítvány a Public Relations Fejlesztéséért. 132-147.

Veszelszki, Ágnes (2017) Die Emotionalisierung des Diskurses über Politik in FacebookKommentaren. Eine rhetorische Analyse. Konferenciaelőadás. Emotionalisierung in der Politik, Konrad-Adenauer-Stiftung. Cadenabbia (Olaszország), 2017. június 17. 
Veszelszki, Ágnes (szerk.) (2012) Netszótár.@-tól a Zukbergnetig. Budapest, ELTE Eötvös Kiadó.

Wallace, Patricia (2006) Az internet pszichológiája. Budapest, Osiris. Eredetiben: (1999) The Psychology of the Internet. Cambridge, Cambridge University Press. https://doi.org/10.1017/cbo9780511581670

\section{Internetes források}

Camber, Rebecca - Neville, Simon (2011) Sick internet 'troll' who posted vile messages and videos taunting the death of teenagers is jailed for 18 WEEKS. Daily Mail. Online: http://www.dailymail.co.uk/news/article-2036935/Natasha-MacBryde-death-Facebookinternet-troll-Sean-Duffy-jailed.html

Doyle, Jennifer (1989) <hick!> Google Groups. 14. 12. 1989. https://groups.google.com/forum/\#!msg/alt.callahans/SphfCkUsdtY/FggkP4rvoQEJ

Elliott, Amy-Mae (2015) How to debate the big issues on social media. Mashable. http://mashable.com/2015/03/16/social-media-etiquette-debates/ [2016. 09. 15.]

Maddox, Thomas (1989) Re: CyberSpacee Conference. 22. 10. 1989. Google Groups. https://groups.google.com/forum/\#!msg/alt.cyberpunk/976Vj979FPX973Q/973Ytxg$\underline{\mathrm{JeCdMJ}}$

Rampton, John (2016) 5 powerful ways social media has forever altered the way we do business. Mashable.

http://mashable.com/2016/09/14/5-ways-social-media-changed-business/ [2016. 10. 06.]

$\mathrm{W} 1$ = Troll. Online Etymology Dictionary. http://www.etymonline.com/index.php?term=troll [2016. 10. 26.]

$\mathrm{W} 2=$ Troll. Merriam-Webster . http://www.merriam-webster.com/dictionary/troll [2016. 10. 26.]

$\mathrm{W} 3$ = Trolling. Know your Meme. http://knowyourmeme.com/memes/subcultures/trolling [2016. 10. 26.]

$\mathrm{W} 4=\mathrm{KFC}$ confirm: Deep fried rat is actually chicken. Telegraph . http://www.telegraph.co.uk/foodanddrink/foodanddrinknews/11695506/KFC-confirmdeep-fried-rat-is-actually-just-chicken.html [2016. 10. 06.]

W5 = Trollfoci. https://www.facebook.com/trollofoci/ [2016. 10. 26.]

$\mathrm{W} 6=$ Trollface. Know your Meme. http://knowyourmeme.com/memes/trollface-coolface-problem [2016. 10. 26.] 